\title{
二次性メトヘモグロビン血症の既往をめつ患児の歯科治療
}

\author{
宮城島俊雄・根尾尚志・小田義浩 \\ 鬼塚博之・西脇孝彦
}

\section{Dental treatment for a patient with an anamnesis of the secondary methemoglobinemia}

\author{
Toshio Miyagishima $\cdot$ Hisashi Neo Yoshihiro Oda \\ Hiroyuki OnIzuka $\cdot$ Takahiko $\cdot$ Nishiwaki
}

\begin{abstract}
We performed a dental treatment for a 5-year-old patient with an anamnesis of secondary methemoglobinemia at his age of 6 months. This may have been caused by PL granules. Though local anesthesia was required for the treatment, amide typed local anesthetic agents such as prilocaine and lidocaine are known to cause methemoglobinemia. During the treatment we thus checked his blood methomoglobin concentrations before and after local anesthesia ( $1.8 \mathrm{~m} l$ lidocaine) to examine a possible causal relationship between lidocaine and increased blood methemoglobin levels. We used an autographic spectrum photometer (UV-265 from SHIMAZU) to determine the methemoglobin concentration in accordance with a revised Evelyn-Malloy method.

As a result, we found no significant rise in the blood methemoglobin concentration at the dose level of lidocaine employed in this case.
\end{abstract}

Key words: methemoglobinemia (メトヘモグロビン血症), local anesthesia (局所麻酔), dental treatment（蒾科治療）

\section{緒言}

ヘモグロビン $(\mathrm{Hb})$ のへム鉄は二俩であるが, この 二価の一ム鉄が酸化されて，三価の第二鉄となったもの をメトへモグロビン (met-Hb) とよび，これは酸素運 搬能力をもたない.

赤血球内の $\mathrm{Hb}$ 絶光す酸化して met-Hb に変化して いるが， met-Hb 還元酵素の㗢きにより $\mathrm{Hb}$ に還元さ れ, $\mathrm{Hb}$ と met-Hb の平衡は維持されている。この と met- $\mathrm{Hb}$ の平衡が崩れ, met- $\mathrm{Hb}$ 含有量が正常籁囲 を越えて增加し，チアノーゼなどの症状を呈するよらに なったものを met-Hb 血症と呼ぶ.この met-Hb 血症 には先天性のものと, 特定の薬剂や有毒物質によって引 き起こされる二次性のものとがあり, 通常われわれが臨

藤枝市立志太総合病院菌科口腔外科

(主任：宮城岛俊雄科長)

Department of Dent-Oral Surgery, Shida General Hospital (Chief: Toshio Miyagishima)

受付日: 平成 2 年 3 月 26 日
東で用いるアミド型の局麻薬も誘発薬耠の1つであると 考えられている。

今回われわれは薬剤による二次性の met-Hb 血症の 既往をもつ患児に対し籶科治療を行万機会を得た。その 際，麻酔下での処置が必要とされたが，患胃は今後も齿 科治療をらける可能性が十分に考兄られ，そのたびに全 麻下での処置といらわけに注いかないため, さらに加粹 に上る変化子十分に子想されるところから，急性 met$\mathrm{Hb}$ In症が発症した場合の準備をととのえた後，局所麻 唒薬としてリドカインを選択し治療を行った。そして， $2 \%$ リトカイン浸潤麻酔下での治療前後で静脈血中の met-Hb 濃度を测定し, その変動について検討した。

\section{症例}

患者：5歳 男児.

主 訴: D|D の冷水痛.

既往歴：生後 6 か月時に PL 顆粒によるものと思われ る二次性の met-Hb 血症の既往がある以外, 特記事項 なし. 
家族歴：特記事項なし。

現 症：外観上チアノーゼなどの異常はなく、すべて の面で普通の子供と何ら変わりがない。

臨床検査所見：血液，生化学検査に異常は認められな かった。一部を表1に示した。

処 置: $\mathrm{D} \mid \mathrm{D}$ の齵蝕は象牙質まで達しており歯牙切 削時, 浸潤麻酔が必要とされた。そこで, 図1に示す方 法で 術前, 術後に採血し, 血中 met-Hb 濃度を測定

表 1 臨床検査值

\begin{tabular}{crcr}
\hline $\mathrm{WBC}$ & 7,000 & ヘモグロビン分画 \\
$\mathrm{RBC}$ & $414 \times 10^{4}$ & $\mathrm{HB}-\mathrm{A}$ & $98.6 \%$ \\
$\mathrm{Hb}$ & $12.5 \mathrm{~g} / \mathrm{d} l$ & $\mathrm{HB}-\mathrm{F}$ & $0.0 \%$ \\
$\mathrm{Ht}$ & $34.8 \%$ & $\mathrm{HB}-\mathrm{AZ}$ & $1.4 \%$ \\
Platelet & $30.7 \times 10^{4}$ & 胎性へモグロビン & $0.9 \%$ \\
& & & 0
\end{tabular}

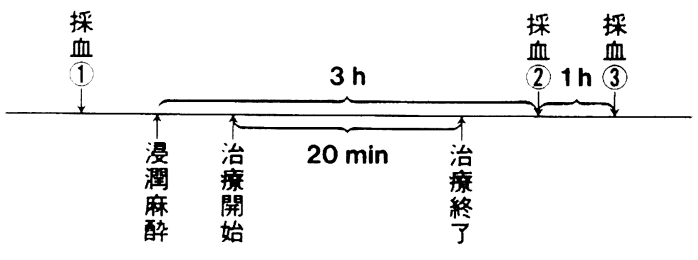

図 1 治療ならびに採血方法
した。浸潤麻酔には既製のエピネフリン含有 $2 \%$ ドカ インを $1.8 \mathrm{ml}$ 使用し, 治療内容は窩洞形成後, ケロン シルバー充填を行った。

\section{血中 met-Hb 濃度の測定方法}

今回われわれが行った met-Hb 血中濃度の測定法(図 2) は Evelyn-Malloy 改良法 ${ }^{2}$ に準拠し, 島津社製自記 分光光度計 UV-265 を用い，可視部吸収曲線を測光す ることにより定量した。すなわち，検体 $0.2 \mathrm{ml}$ に 0.15 M phosphate buffer $10 \mathrm{ml}$ を加え罍汼， 3 分間経過後 2 本の試験管に $2 \mathrm{ml}$ ずつ分注した（1本を $\mathrm{A}$ ，他方を B). A の試験管内容液をセルに注ぎ $630 \mathrm{~nm}$ の波長で 測光し，その数值を $\mathrm{E}_{1}$ とした。続いてAの試験管に 5 $\mathrm{g} / \mathrm{d} l \mathrm{KCN} 0.02 \mathrm{~m} l$ を加え揌挥し，その数值を $\mathrm{E}_{2}$ と した。次に B の試験管に $5 \mathrm{~g} / \mathrm{d} l \mathrm{~K}_{3} \mathrm{Fe}(\mathrm{CN})_{6} 0.02 \mathrm{ml}$ を加光摜抖し， 3 分後同様にして $630 \mathrm{~nm}$ で測光しその 値を $\mathrm{E}_{3}$ とした。最後にBの試験管に $5 \mathrm{~g} / \mathrm{d} l \mathrm{KCN} 0.02$ $\mathrm{m} l$ を加光同様の操作後测光し， その值を $\mathrm{E}_{4}$ とした. 以上，测定した $\mathrm{E}_{1} \sim \mathrm{E}_{4}$ までの值を $\left(\mathrm{E}_{1}-\mathrm{E}_{2}\right) /\left(\mathrm{E}_{3}-\mathrm{E}_{4}\right)$ ×100にあてはめると, met-Hb の血中濃度がパーセン テージで算出される。これは, met-Hb の赤血球溶血液 の可視部吸光曲線が $630 \mathrm{~nm}$ で吸収を示し, $\mathrm{K}_{3} \mathrm{Fe}(\mathrm{CN})_{6}$ を加えることによって met-Hb がシアン met-Hb とな り, $630 \mathrm{~nm}$ の吸収が消失し， $540 \mathrm{~nm}$ に吸収がみられ るようになることと， $\mathrm{KCN}$ を加えることによって血液 中の $\mathrm{Hb}$ がすべて, met-Hb に変化することを利用し たものである.

血液 $0.2 \mathrm{ml}$

$+$

浴解試薬 $10 \mathrm{ml}(\mathrm{pH} 6.8)$

(0.1 M phosphate buffer 4 容 $+1 \%$ ト リトン×100 6 㝘)

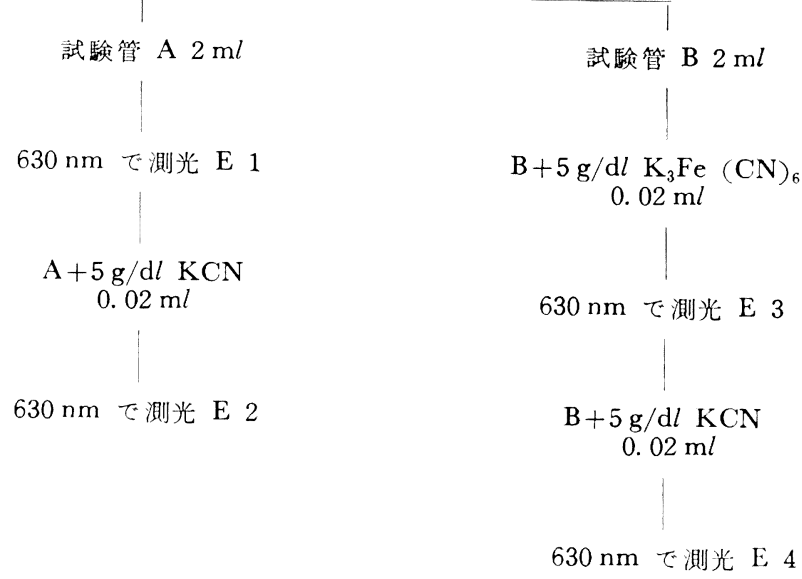

(E 1-E 2)/(E 3-E 4) =メトーモグロビンの伹中沸度\%

图 2 血中メトヘモグロビン濃度の測定法 (Evelyn and Malloy 改良法) 
表 2 測定結果

\begin{tabular}{|c|c|c|c|}
\hline & $\begin{array}{l}\text { 浸潤庥酷 } \\
\text { 施行前(1) }\end{array}$ & $\begin{array}{l}\text { 浸潤麻酔施行 } \\
3 \text { 時間後 } 2\end{array}$ & $\begin{array}{l}\text { 浸潤麻酔施行 } \\
4 \text { 時間後 } 3\end{array}$ \\
\hline $\begin{array}{l}\text { メトモモグロビン } \\
\text { 血中濃度 }(\%)\end{array}$ & 1. 99 & 1. 90 & 2. 07 \\
\hline
\end{tabular}

結

\section{果}

血中 met-Hb 濃度はコントロールで $1.99 \%$ ，浸潤麻 酔施行 3 時間後で， $1.90 \% ， 4$ 時間後で $2.07 \%$ と 4 時間 後に多少増大傾向を示したものの，明らかな変化ではな かった。また，臨床所見においても何ら異常は認めなか った（表 2 ).

\section{考察}

先天性の met-Hb 血症は通常 3 つに分類され, その 1 つは先天性の血色素異常症として, 常染色体優性遺伝 の形式をとる異常血色素 $\mathrm{HbM}$ による $\mathrm{HbM}$ 症などで あり，2つめは，met-Hb 還元酵素が欠如または低下し ているために met-Hb が增加するもので，これは常染 色体劣性遺伝の形式をとる。 3 つめは $\mathrm{Hb}$ の酸化過程の 異常六進によるもので, 大部分は非酵素的反応であると いわれている3).

一方, met- $\mathrm{Hb}$ 血症の大部分を含める薬物による二次 性の met-Hb 血症に関しては，それを誘発すると考光 られている薬物を表了に示した4,5) 今回の患巟の場合， PL 顆粒はその成分であるアセトアミノフェンがアミ， フェノール系の解熱鎮痛薬であるところから，これが誘 発薬剤であると考えられた。

また，局麻薬，とくにアミド型局麻薬はその使用時に ときに著明な met-Hb 血症をみることがあるといわれて おり ${ }^{6)}$, やはり誘発薬剤の 1 つに考えられている.とくに プリロカイン使用時の報告がいくつかなされて扣り ${ }^{1,7)}$, このプリロカインの met- $\mathrm{Hb}$ 形成は, プリロカインの 代謝産物のためであると考えられている ${ }^{8)}$. これに対し， リドカインの報告はほとんどなく， Nishimura ஆ 2 ( $3 \%$ リ゚リカイン，2\%リドカインを持続硬膜外麻酔の ために投与し，その際の血中 met-Hb 量を測定した. プリロカインを投与した場合には，血中 met-Hb 量の 増加を認めたが，リドカインでは血中 met-Hb 量の増 加は認められなかったと報告している。

そこで，今回リドカイン使用によって met-Hb 濃度 にほとんど変化をきたさなかったといら結果に対して は,

1. 新生児期の $\mathrm{Hb}$ の $80 \%$ HbF である， $\mathrm{NADH}$ diaphoraseの量の問題，といった新生児期，乳児期にも
表 3 二次性ハトへモグロビン血症を誘発すると考 えられている楽物

Amino and Nitro Compounds Producing Methemoglobinemia

\begin{tabular}{l|l}
\multicolumn{1}{|c|}{ Aromatic Drugs } & $\begin{array}{l}\text { Aliphatic and Inorganic } \\
\text { Drugs }\end{array}$ \\
\hline Aniline & $\begin{array}{l}\text { Sodiumnitrite } \\
\text { Anilinocthanol }\end{array}$ \\
Phenacetin & $\begin{array}{l}\text { Dimethylamine } \\
\text { Nitroglycerin }\end{array}$ \\
Acetanilid & $\begin{array}{l}\text { Amylnitrite } \\
\text { Methylacetanilide } \\
\text { Hydroxylacetanilide }\end{array}$ \\
$\begin{array}{l}\text { Prontosil } \\
\text { Sulfanilamide }\end{array}$ & $\begin{array}{l}\text { Ethylnitrite } \\
\text { Sulfapyridine }\end{array}$ \\
Sulfathiazole & Ammoniumnitrate \\
Phenilenediamine & \\
Aminophenol & \\
Toluencdiamine & \\
Alphanaphylamine & \\
Paraminopropiophenone & \\
Phenylhydroxylamine & \\
Tolyhydroxylamine & \\
Nitrobenzen & \\
Dinitorobenzen & \\
Trinitrotoluene & \\
Nitrosobenzen & \\
Paranitoraniline & \\
& \\
& \\
\hline
\end{tabular}

New England J Med 239: 470-478 1948.

つ特殊性が加粭とともに消失していたため。

2. 局麻薬による met-Hb 血症は，血中の局麻薬濃度 と出現する met-Hb 濃度との間に著明な個体差がある といわれているところから，単に個体差によるもの.

3.リドカイン使用量の問題.

4. 従来よりいわれているアミド型局麻薬使用による met-Hb 血症はプリロカイン使用時に多く、リドカイン での報告はほとんどないところから，同じアミド型であ っても，リドカインはプリロカインよりも met-Hb 形 成に対して安全であるといった可能性が考えられるが， 今回の結果だけからは, 明確な結論つけはは不可能であり, 
今後種々な症例, さらに他の局麻薬での検討も必要であ 万5.

次に，チアノ一ゼをきたした急性 met-Hb 血症の治 療に関しては, 従来メチレンブルーの静脈内投与が行わ れてきたが，これは同時に強力な $\mathrm{Hb}$ の酸化剂であり， 過量では逆にチアノーゼを起こす可能性や急性溶血性負 血の危険もあるところから，最近では 5 価の糖アルコー ルであり，met-Hb 還元作用をもつ，キシリトールの使 用がまずすすめられている10,11)。

すなわち， $10 \%$ キシリトール $1 \mathrm{~g} / \mathrm{kg}$ を $2 \sim 3 \mathrm{ml} / \mathrm{min}$ の割合で点滴静注する方法で，この方法では溶血過血糖 をみたものはなく，また電解質の変動もないといわれて いる。今回，われわれも治療開始前に静脈路を確保し， 10\%キシリトールおよびメチレンブルーなどを用意し治 療を開始した。

\section{結語}

二次性 met-Hb 血症の既往をもつ患児に対し，その 誘発薬剤の1つと考えられているリドカイン浸潤麻酔下 に歯科治療を施行した。

術前，術後で患児の血中 Met-Hb 濃度を测定した結 果, 今回の症例では，一般米科治療に用いられる程度の リドカイン量では, 臨床上問題となるほどの明らかな血 中 met-Hb 濃度の上昇は認められなかった。

\section{引用文 献}

1) Crawford, O.B.: Methemoglobin in man following the use of prilocaine. Acta anaesth
Scandinav Supp XVI : 183-187 1965.

2) Evelyn, K.A. and Malloy, H.T.: Microdetermination of oxyhemoglobin, methemoglobin, and sulfhemoglobin in a single sample of blood. J Biol Chem 126: 655-662 1958.

3）藤田之彦，箖郁代，他：新生児メトへモグロ ビン血症の2 例. 周産期医学 13：619-623 1983-4.

4) Finch, C.A.. Methemoglobinemia and sulfhemoglobinemia. N Eng J Med 239: 470-478 1948.

5）藤田之彦, 三沢正弘, 他：薬物中毒によるメ卜 ヘモグロビン血症。小児内科 19：365-369 1987.

6) 小方明子, 山下九三夫, 他 : メトへモグロビン 血症と麻酔. 麻酔 22: 586-591 1973.

7) Daly, D.J., Davenport, J., et al.: Methemoglobinaemia following the use of prilocaineA preliminary report. Brit $\mathrm{J}$ Anaesth 36: 737-739 1964.

8) Onji, Y. and Tyuma, I.: Methemoglobin formation by a local anesthetic and some related compounds. Acta anaesth Scandinav Supp XVI : 151-159 1965.

9) Nishimura, K.. Methemoglobinemia due to local anesthetics. Osaka City Medical Journal 17: 25-42 1971.

10）本城繁, 岡田和夫, 他：局麻剤によるメト一 モグロビン血症とキシリトール。麻酥 17：3543571968.

11）鉿木長明：局所麻酔薬による事故とその対策 一局所ならびに全身一曾科 シ ャーナル17: 789-795 1983. 